\title{
Model Pengembangan Buku Ajar Pengayaan Membaca Seloko Adat Melayu Jambi di SMP
}

\author{
Kamarudin, Eddy Pahar \\ FKIP, Universitas Jambi \\ Email corresponding author: kamarudinnn@yahoo.com/eddyfkip@gmail.com
}

\begin{abstract}
ABSTRAK
Jambi memiliki seloko yang menarik baik isi maupun bentuknya. Pembelajaran, seloko Melayu di Jambi belum sepenuhnya dipelajari di dunia pendidikan, seperti yang dituntut oleh Kurikulum-13. Semestinya seloko direncanakan dalam pembelajaran di selokah. Berdasarkan survei yang dilaksanakan peneliti di daerah Batanghari, Jambi diperoleh sejumlah seloko Melayu. Seloko tersebut belum dirancang dengan baik sebagai bahan ajar bahasa dan sastra Indonesia di SMP, terutama dalam pembelajaran keterampilan membaca. Membaca adalah keterampilan penting yang wajib dikuasai oleh siswa. Kemampuan membaca bisa diperoleh melalui kegiatan latihan, tetapi keberadaan buku ajar sebagai penunjang penguasaan materi betul-betul diperlukan. Buku ajar menyediakan materi pembelajaran yang tersusun untuk keperluan guru dan siswa. Berdasarkan latar belakang masalah di atas, perlu dilakukan penelitian dan pengembangan buku ajar seloko yang mengintegrasikan seloko adat Jambi ke dalam Kurikulum-13, khusunya keterampilan membaca. Penelitian ini bertujuan menghasilkan buku ajar pengayaan membaca seloko yang sesuai dengan kebutuhan guru dan siswa. Metode yang digunakan dalam penelitian adalah metode deskriptif dengan teknik pengumpulan data seperti teknik ovservasi, teknik wawancara, dan analisis dokumen. Data di analisis berdasarkan langkah dikemukakan Milles (1984) yakni: (1) pengumpulan data, 2) reduksi data, (3) penyajian data, (4) simpulan. Pengembangan buku ajar, berdasarkan teori pengembangan Borg dan Gall (1983), yaitu; (1) survey awal (2) pengembangan draf, (3) pengujian draf (4) pengenalan produk.
\end{abstract}

Kata Kunci: Model, pengembangan, buku ajar, seloko

\section{PENDAHULUAN}

Seloko daerah Jambi berasal dari bahasa Sansekerta, yaitu cloka bentuk puisi dalam Mahabrata dan Ramayana di India. Sajak-sajaknya amat sederhana, terdiri dari empat sampai delapan suku kata, tidak terlalu memperhatikan persajakan, sedangkan dalam bahasa Melayu yang dimaksudkan dengan seloko adalah puisi yang terdiri delapan sampai sebelas suku kata dan bersajak a-a-a-a. Kemudian jumlah barisnya tidak ada ketentuannya, dapat dua baris atau lebih dan persajakannya tidak teratur, tetapi berirama serta mengandung nilai-nilai kehidupan. Seloko di daerah Jambi dilestarikan secara lisan dari generasi ke kenerasi.

Seloko Melayu daerah Jambi sangat bagus baik dari isi maupun bentuknya dan kental dengan kedaerahannya, yaitu budaya Melayu. Sementara seloko tersebut dalam pembelajaran sastra belum prioritas untuk dipelajari, seperti yang dituntut oleh Kurikulum-13. Seharusnya seloko itu diprogramkan di buku ajar atau LKS di sekolah menengah pertama, karena seloko Melayu mengandung ajaran petuah-petuan dan pesan-pesan moral yang disampaikan dengan bahasa Melayu dialek Jambi.

Jambi memiliki seloko yang menarik baik isi maupun bentuknya dan sarat dengan kedaerahannya, yaitu budaya Melayu Jambi. Pembelajaran, seloko Melayu di Jambi belum sepenuhnya digunakan di sekolah, seperti yang dituntut oleh Kurikulum-13. Semestinya seloko tersebut direncanakan dalam buku pembelajaran di selokah karena seloko tersebut mengandung nilai-nilai kehidupan yang kontekstual. Berdasarkan pengamatan yang dilaksanakan peneliti di daerah Batanghari, Jambi diperoleh sejumlah seloko Melayu. Seloko tersebut belum dirancang sebagai materi ajar di pelajaran bahasa Indonesia di SMP sebagai muatan lokal, terutama pembelajaran keterampilan membaca seloko Melayu. Membaca adalah 
keterampilan penting yang wajib dikuasai oleh siswa. Pemasalahan ini bisa dipahami sebab membaca merupakan kegiatan yang bersifat reseptif. Reseptif berarti memahami sesuatu dari tulisan termasuk seloko. Pemahaman siswa terhadap seloko dapat menunjukkan seberapa jauh kemampuan siswa membaca. Kemampuan membaca bisa diperoleh melalui kegiatan latihan, tetapi keberadaan buku ajar sebagai penunjang penguasaan materi betul-betul diperlukan. Buku ajar menyediakan materi pembelajaran yang tersusun untuk keperluan siswa. Buku ajar sangat dibutuhkan dalam kegiatan pembelajaran, baik guru atau siswa. Terlebih buku tersebut betul-betul dapat menggali kompetensi yang dimiliki siswa secara utuh, sehingga buku ajar dapat meningkatkan kualitas pendidikan. Menurut Pusat Perbukuan, (2006: 3) Buku ajar adalah buku yang digunakan sebagai sarana belajar di sekolah untuk menunjang program pembelajaran di sekolah.

Buku ajar menyediakan materi yang tersusun untuk keperluan pembelajaran siswa. Muslich (2010: 23) mengatakan buku merupakan bagian dari kelangsungan pendidikan. Guru dapat mengelola kegiatan pembelajaran secara efektif dan efisien melalui sarana buku. Siswa pun dapat mengikuti kegiatan pembelajaran secara maksimal dengan sarana buku. Oleh karena itu, buku ajar sangat penting dalam kegiatan pembelajaran di sekolah, baik untuk guru maupun siswa. Terlebih apabila buku tersebut benar-benar mampu menggali kompetensi yang dimiliki siswa secara maksimal, sehingga buku ajar mampu meningkatkan kualitas pendidikan.

Berdasarkan latarbelakang di atas, perlu dilakukan penelitian dan pengembangan buku ajar yang mengintegrasikan seloko ke dalam kurikulum-13, khususnya keterampilan membaca. Penelitian ini bertujuan menghasilkan buku ajar membaca seloko adat yang sesuai dengan kebutuhan guru atau siswa.

\section{METODE PENELITIAN}

Penelitian ini terdiri dari dua tahap. Tahap pertama mengidentifikasi dan mendeskripsi seloko adat Melayu Jambi, peneliti menggunakan metode yang dikemukakan oleh Suwardi (2002: 105), yaitu: 1) melalui pembacaan heuristik, 2) melalui pembacaan hermeneutik, 3) wawancara, 4) kuesioner, dan 5) pengamatan. Tahap kedua pengembangan model buku ajar, berdasarkan pengembangan oleh Borg dan Gall (1983:775) yang terdiri dari pengembangan produk, uji coba, dan perbaikan. Perumusan model buku ajar, penulis berdasarkan standar buku ajar Direktorat Jenderal Pendidikan Tinggi yakni: (1) prakata, (2) daftar Isi, (3) batang tubuh yang terdiri dari bab-bab beserta tujuan instruksional, (4) daftar pustaka, (5) glosarium, (6) Indeks (sebaiknya).

\section{HASIL DAN PEMBAHASAN}

\subsection{Pengembangan Buku Ajar}

Produk yang dikembangkan adalah buku ajar pengayaan membaca seloko adat Melayu di sekolah menengah pertama sederajat. Bahan ajar ini dilengkapi dengan panduan pengajar dan latihan. Bahan ajar dirancang dua bab. Bab-bab tersebut memuat topik yang berbeda dan fungsional sehingga dapat langsung dipraktekkan oleh guru dan siswa. Setiap bab memiliki tinjauan mata pelajaran, deskripsi singkat mata pelajaran, kegunaan mata pelajaran, standar kompetensi, dan petunjuk bagi siswa dan guru.

Bab satu hingga dua diuraikan berbagai macam materi, contoh, dan latihan. Bagian tiga adalah latihan untuk siswa. Bagian tiga ini dapat digunakan guru untuk melihat seberapa jauh kemampuan pemahaman siswa serta kesulitan apa saja yang dialami oleh siswa. Judul sub bab tersebut dibuat sekomunikatif mungkin, yaitu (1) mengidentifikasi bentuk fisik seloko, dan (2) menelaah struktur batin seloko yang dibaca. 


\subsection{Sistematika Penyajian Buku Ajar}

Sistematika penyajian buku ajar didasarkan pada standar buku ajar yang ditetapkan Direktorat Jenderal Pendidikan Tinggi yaitu: Judul, prakata, daftar Isi, batang tubuh, daftar pustaka, glosarium, dan Indeks (sebaiknya). Sebagai contoh sistematika rancangan buku ajar seloko adat Melayu Jambi sebagai berikut.

1) Judul: "Model Pengembangan Buku Ajar Pengayaan Membaca Seloko Adat Melayu di SMP"

2) Prakata

Prakata dirancang berisi mengapa buku ditulis, siapa pengguna buku, bagaimana struktur buku, dan apakah ada pesan khusus bagi pengguna buku ajar.

3) Daftar isi

Daftar isi berisi; prakata, tinjauan mata pelajaran, daftar isi, Bab I Mengidentifikasi. Bentuk Fisik Seloko, dan Bab II Menelaah Struktur Batin Seloko yang Dibaca.

4) Tinjauan Mata Pelajaran

(1) Deskripsi Singkat Mata Pelajaran

Mata pelajaran ini menyajikan tentang seloko adat Melayu Jambi yang terdiri dari struktur fisik dan struktur batin.

(2) Kegunaan Mata Pelajaran

Dengan mengikuti mata pelajaran seloko adat Melayu Jambi, siswa akan memperoleh wawasan baru serta mampu menjelaskan tentang seloko adat Melayu Jambi.

(3) Petunjuk Bagi Siswa

Untuk mempermudah siswa mempelajari buku ajar ini, dapat dilakukan dengan langkah-langkah berikut: 1) Bacalah buku ini dengan teliti dan kerjakanlah latihan serta tes formatif disetiap bab. 2) Buku ini dipelajari secara sistematis dan berkelompok.

(4) Batang Tubuh

Berikut ini penulis menyajikan bentuk batang tubuh buku ajar pengayaan membaca seloko adat Melayu di SMP yang terdiri dari; Judul bab, pendahuluan, penyajian materi, latihan, daftar bacaan, dan glosarium.

\section{Bab I Mengidentifikasi Bentuk Fisik Seloko}

\section{Pendahuluan}

1. Deskripsi Singkat : Bab ini berisi pertama siswa membaca beberapa seloko adat Melayu Jambi. Kedua siswa mengidentifikasi bentuk fisik seloko adat Melayu Jambi.

2. Relevansi

Pemahaman melalui membaca seloko adat Melayu Jambi akan menjadi dasar bagi siswa untuk memahami seloko.

Mencoba, mengolah, dan menyaji dalam ranah konkret

3. Kompetensi inti : (menggunakan, mengurai, merangkai, memodifikasi, dan membuat) dan ranah abstrak (menulis, membaca, menghitung, menggambar dan mengarang)sesuai dengan yang dipelajari di 
sekolah dan sumber lain yang sama dalam sudut pandang teori KI3 (Kurikulum, 2013)

4. Kompetensi Dasar : Menyajikan tanggapan secara lisan, tulis dan visual terhadap isi buku fiksi/ non fiksi yang dibaca.4.10 (Kurikulum, 2013)

\section{Penyajian Materi}

\section{Struktur Fisik Seloko Adat Melayu Jambi}

Struktur fisik seloko adat Melayu Jambi yaitu diksi, imaji, kata kongkret, bahasa figurative, rima dan ritme.

1. Diksi

Diksi adalah pemilihan kata dalam penciptaan puisi atau seloko. Pada seloko adat Melayu Jambi ditemukan pemilihan kata yang berkaitan dengan makna denotatif (sebenarnya) dan makna konotatif (tidak sebenarnya).

Contoh seloko (1)

Musin elok ketiko baik,

Teluk tenang

Rantau selesai

Padi menjadi

Pada contoh seloko (1) ditemukan diksi atau pemilihan kata bermakna denotatif atau makna sebenarnya, diksi tersebut terlihat pada kutipan baris kedua, yaitu "teluk tenang" artinya keadaan air di teluk baik di laut atau di sungai benar-benar tenang, tidak ada ombaknya. Denotatif juga ditemukan pada baris keempat, yaitu "Padi menjadi" artinya seorang petani sedang bernasib baik, karena tanaman padinya bisa panen memuaskan.

Contoh seloko (2)

Kaayek cemeti keno,

Ke darat jerat keno

Balek kerumah durian runtuh

Naik kerumah anak lah lahir

Ke dapur lemang lah terjulur

Pada contoh seloko (2) ditemukan pemilihan kata bermakna konotatif atau makna tidak sebenarnya, contoh "Balek kerumah durian runtuh". Durian runtuh, bukanlah makna sebenarnya. arti sebenarnya durian runtuh adalah seseorang mendapat rezki yang banyak atau melimpah ruah.

2. Imaji

Imaji dalam seloko Melayu Jambi, yaitu penggambaran sesuatu melalui kata-kata yang seolah-olah dapat dilihat, didengar, maupun dirasa.

1) Melihat

Penggambaran sesuatu melalui kata-kata yang seolah-olah dapat dilihat dapat dijumpai pada seloko berikut.

Tatukik tainjak lalu naik

Tasaloso tainjak lalu turun

Tepekik tapikau

Condong mato orang banyak

Imaji melihat terdapat pada baris keempat, yaitu: "Condong mato orang banyak”. Jika kita baca seloko tersebut seolah-olah kita diajak melihat secara jeli terhadap suatu 
kejadian, apabila terinjak lalu naik, artinya berhati-hatilah dalam bertindak atau membuat keputusan, karena setiap keputusan yang diambil selalu ada perlawanan.

2) Mendengar

Penggambaran sesuatu melalui kata-kata yang seolah-olah dapat didengar dapat dijumpai pada seloko berikut.

Ayam putih terbang siang

Hinggap dikayu merangeh

Tajilo-jilo dan tedengar pulo kukuknyo

Imaji mendengar dapat dijumpai pada kata-kata "Tajilo-jilo dan tedengar pulo kukuknyo" Baris ketiga, seolah-olah kita mendengar kukuk ayam. Baris ketiga ini menggambarkan bahwa perbuatan jahat atau buruk yang terjadi di masyarakat tidak dapat disembunyikan, selalu saja kabarnya terdengar. Maka berhati-hatiklah berbuat kejahatan.

3) Rasa

Penglukisan sesuatu melalui kata-kata yang seolah-olah dapat dirasa dijumpi pada seloko berikut.

Ibarat buah banyak raso

Ibarat bungo banyak mambu

Seloko adat Jambi ini memiliki imaji rasa, seperti terlihat pada kata-kata baris pertama, yaitu "Ibarat buah banyak raso". Pada tuturan baris pertama ini kita mendapat gambaran bahwa kehidupan ini seperti buah banyak jenisnya dan banyak pula rasanya. Begitu pula kehidupan ini, kadang-kadang kita merasa kehidupan ini manis sekali atau enak benar, sebaliknya kehidupan ini ada juga pahit atau susahnya.

3. Kata Kongkret

Kata kongkret adalah kata-kata yang dapat menggambarkan keadaan sebenarnya, dapat dilihat, dapat diraba, dan sebagainya. Contoh kata kongret dalam seloko Melayu Jambi sebagai berikut.

\section{Ke bukit samo mendaki}

Ke lurah samo menurun

Penggunaan kata kongkret pada seloko Melayu Jambi ini terlihat pada baris pertama, yaitu "Ke bukit samo mendaki" Kata 'bukit" benar-benar ada dan dapat dilihat atau diraba. Bukit adalah tanah tumbuh menjulang ke atas, bukit dapat didaki oleh siapapun yang menghendakinya.

4. Bahasa figurative

Bahasa figuratif adalah pengungkapan suatu maksud dengan cara tidak langsung. Seloko Melayu Jambi juga menggunakan bahasa figuratif. Contoh:

Dak lapuk dek ujan

Dak lekang dek panas

Kato nan seiyo

Pengungkapan suatu maksud dengan cara tidak langsung pada seloko Melayu Jambi terlihat pada baris pertama dan kedua, yaitu:

Dak lapuk dek ujan

Dak lekang dek panas

Maksud yang terkandung pada baris pertama dan kedua adalah sesuatu yang benarbenar tahan dari pengaruh apapun, tidak akan terjadi perubahan padanya baik mendapat pengaruh besar maupun pengaruh kecil.

5. Rima 
Rima adalah pengulangan bunyi dalam seloko. Fungsi rima adalah memperindah bunyi seloko yang didendangkan. Rima banyak ditemukan dalam seloko Melayu Jambi di antaranya rima $/ n g /$ dan $/ k /$. Contoh :

Nan datang dari muaro

Jangan balek ke ilir

Nan datang dari laut

Jangan balek ke permukoan

Seloko di atas memiliki rima atau persamaan bunyi / $n g /$ pada baris pertama dengan baris ketiga yakni rima $/ n g /$, sedangkan pada baris kedua dan keempat adalah rima atau persamaam bunyi $/ k /$.

\section{Latihan}

1. Jelaskan dengan singkat apa yang dimaksudkan dengan struktur fisik seloko adat Melayu Jambi.

2. Berilah contoh kata yang bermakna konotatif dan denotatif dalam seloko adat Melayu Jambi.

3. Temukan rima dalam seloko berikut ini !

Bujuk rayu, ugut agat

Tipu tepo, samun sakal

Bersengelak segan keno

Tergamang segan jatuh

4. Jelaskan bahasa figurative seloko adat Melayu berikut ini !

Terlampau arif badan celako

Tidak arif badan binaso

Jangan berfikir sekali lalu

Jangan berhemat sekali sudah

\section{Bab II Menelaah Struktur Batin Seloko yang Dibaca}

\section{Pendahuluan}

1 Deskripsi Singkat : Tahap pertama siswa membaca seloko adat dan tahap kedua siswa menelaah struktur batin seloko adat Melayu.

2 Relevansi : Pemahaman struktur batin seloko akan menjadi dasar bagi siswa untuk memahami seloko.

3 Kompetensi Inti : Mencoba, mengolah dan menyaji dalam ranah konkret (menggunakan, mengurai, merangkai, memodifikasi, dan membuat) dan ranah abstrak (menulis, membaca, menghitung, menggambar dan mengarang) sesuai dengan yang dipelajari di sekolah dan sumber lain yang sama dalam sudut pandang/ teori (Kurikulum, 2013)

4 Kompetensi Dasar : Menelaah struktur dan kebahasaan puisi rakyat (pantun, syair, dan bentuk puisi rakyat setempat) yang dibaca dan di dengar 3.10 ((Kurikulum, 2013)

\section{Penyajian Materi}

Seloko adat Melayu Jambi memiliki struktur batin yakni tema, amanat, nada, atau suasana, dan rasa atau filling. 
1. Tema

Tema adalah pikiran utama yang dikemukakan oleh penyair dalam karyanya, misalnya fikiran uatama dalam seloko. Tema seloko adat Melayu Jambi di antaranya "adat berbeda-beda", seperti terlihat pada seloko di bawah ini.

Melempar batu kelubuk

Melepas kuaw ke rimbo

Lain lubuk lain ikannyo

Lain padang lain belalang

Baris keempat dan kelima seloko di atas, mengandung tema berbeda adat. Tema tersebut tergambar pada untaian kata "Lain lubuk lain ikannyo" dan "Lain padang lain belalang”. Arti kedua baris seloko tersebut adalah setiap negeri atau bangsa berlainan adat kebiasaannya atau setiap negeri adatnya sendiri-sendiri.

2. Amanat

Amanat seloko adalah pesan-pesan yang terkandung dalam seloko. Seloko adat Melayu Jambi memiliki pesan atau amanat, seperti yang terlihat pada seloko berikut.

Kempas dulu beliung dulu

Kempas kini beliung kini

Sekali aek dalam sekali pulau beraleh

Sekali tanjung putus namun tepian bak lamo jugo

Amanat seloko di atas tertera pada baris keempat, yaitu "Sekali tanjung putus namun tepian bak lamo jugo”. Pesan yang disampaikan melalui seloko ini adalah "tetap pendirian".

3. Nada atau suasana

Nada atau suasana seloko merupakan sikap penyair terhadap pembaca atau pendengar. Sikap penyair dapat berupa menggurui, mendikte, dan sebagainya. Amanat seloko adat Melayu Jambi dapat dilihat pada seloko berikut.

Ayam hitam terbang malam

Himggap di rumpun pandan, ngokok bunyinyo

Salah hukum penghulu pecat

Tidak dihukum penghulu pecat

Lain nan bakotek

Lain nan bertelor

Seloko di atas memiliki sikap "menggurui" yang terdapat pada baris ketiga dan keempat, yaitu "Salah hukum penghulu pecat" dan "Tidak dihukum penghulu pecat". Sikap menggurui di sini adalah mengajar atau mengingat kepada penguasa agar bertindak secara tepat dalam menghukum suatu perbuatan.

4. Rasa atau feeling

Rasa atau feeling seloko merupakan sikap penyair terhadap suatu objek dapat berupa perasaan mendukung maupun tidak mendukung. Sikap dalam seloko Melayu Jambi berikut ini adalah mendukung.

Tibo dibulek mintak aaek

Tibo di lurah minta angin

Sakit samo diubek

Pening samo diureh

Sikap tersebut terlihat pada baris ketiga dan keempat, "Sakit samo diubek" dan "Pening samo diureh".

\section{Latihan}


1. Jelaskan dengan singkat apa yang dimaksudkan dengan struktur batin dan berilah contoh dalam bentuk seloko.

2. Uraikan dengan singkat apa yang dimaksud dengan tema dalam seloko dan berilah contoh.

3. Uraikan dengan singkat apa yang dimaksud dengan amanat dalam seloko dan berilah contoh.

4. Uraikan dengan singkat apa yang dimaksud dengan nada atau suasana dalam seloko dan berilah contoh.

5. Uraikan dengan singkat apa yang dimaksud dengan rasa atau feeling dalam seloko dan berilah contoh.

\section{Glosarium}

Glosarium pada artikel ini adalah makna istilah atau kata-kata baru yang digunakan dalam buku ajar, seperti istilah; seloko, struktur batin, struktur fisik, tema, amanat, rima, nada, dan feeling.

\section{KESIMPULAN DAN SARAN}

\subsection{Kesimpulan}

Seloko Adat Melayu Jambi memiliki struktur fisik dan struktur batin. Hasil penelitian seloko Adat Melayu Jambi dapat dikembangkan menjadi buku ajar seloko yaitu buku ajar muatan lokal. Buku ajar tersebut dapat digunakan sebagai bahan ajar muatan lokal daerah Jambi.

\subsection{2 Saran}

Berdasarkan hasil dan pembahasan dapat disarankan, pertama Seloko Adat Melayu Jambi sebaiknya dilestarikan sebagai khasanah budaya bangsa Indonesia. Kedua seloko Adat Melayu Jambi dapat digunakan sebagai bahan ajar muatan lokal di sekolah pertama sederajat.

\section{DAFTAR PUSTAKA}

DJP DAN KDP. 2017. StandarBuku Ajar dan Modul Ajar . Jakarta. Ristekdikti.Gall, J.P.

Borg, W.R. 2003. Educational research. Boston: Pearson Educational, Inc.

Muslich, Masnur. 2010. Teksbook Writting. Jogjakarta:AR-Ruzz Media.

Miles, Matthew B. And A Michael Huberman. 1984. Qualitative Data Analisis

A Sourcebook of New Methods. London: Sage Publication

Pusat perbukuan. 2006. Pedoman Penilaian Buku Teks Pelajaran Bahasa dan

Sastra Indonesia untuk SMP/Mts dan SMA/MA . Jakarta: Depdiknas

Suwardi Ebdraswara. 2002. Metodologi Penelitian Sosuiologi Sastra. Caps.

Yogyakarta

Kementerian Pendidikan dan Kebudayaan. 2013. Dokumen Kurikulum.

Jakarta. Kemendikbud. 
